Sri Lanka J. Aquat. Sci. 17 (2012): 19-34

\title{
EFFECT OF COPPER IN PROTEIN, CARBOHYDRATE AND LIPID CONTENTS OF THE JUVENILE LOBSTER, PANULIRUS HOMARUS HOMARUS (LINNAEUS, 1758)
}

\author{
A. MAHARAJAN*1\&2, S. RAJALAKSHMI ${ }^{1 \& 3}$ and M. \\ VIJAYAKUMARAN ${ }^{1 \& 4}$
}

${ }^{1}$ Central Marine Fisheries Research Institute, Madras Research Centre, 75 Santhome High Road, Chennai - 600 028, India

${ }^{2} \mathrm{PG}$ and Research Department of Zoology, Khadir Mohideen College, Adirampattinam-614701, Thanjavur Dist., Tamil Nadu, India

${ }^{3}$ Department of Zoology, Kanchi Mamunivar Centre for Post Graduate Studies, Lawspet-605008 Puducherry, India

${ }^{4}$ National Institute of Ocean Technology, Velacherry-Tambaram Road, Pallikaranai, Chennai - 601 302, India

*Correspondence (athimaha@yahoo.co.in)

\begin{abstract}
Copper is one of the most toxic metals for marine organisms. Biochemical changes occurring in the metabolically active tissues of gills (GL), hepatopancreas (HP) and muscles (MU) of the juvenile lobster, Panulirus homarus homarus on exposure to two sub-lethal doses $\left(9.55\right.$ and $\left.19.1 \mu \mathrm{g} \mathrm{l}^{-1}\right)$ of copper were studied for 28 days of exposure (DoE). Sub-lethal doses of copper significantly $(P<0.05)$ altered the levels of the total protein $(\mathrm{TP})$, carbohydrate (TC), and lipid contents (TL) in test lobsters. Percentage decrease in all biochemical components increased with the progressing DoE, irrespective of the exposure concentrations. The order of percent decrease in the concentrations of the TP, TC and TL in different tissues at the end of $28 \mathrm{DoE}$ was found to be $\mathrm{MU}>\mathrm{HP}>\mathrm{GL}, \mathrm{HP}>\mathrm{MU}>\mathrm{GL}$ and $\mathrm{HP}>\mathrm{MU}>\mathrm{GL}$. Results of this study revealed that sub-lethal doses of copper significantly alter the proximate composition of major tissues, particularly the TP levels in the MU tissues and thereby reducing the nutritive value of this economically important spiny lobster.
\end{abstract}

Key words: Copper, Proximate composition, sub lethal dose, Panulirus homarus homarus 


\section{Introduction}

Spiny lobsters have gained considerable attention among the crustaceans due to its high demand in the world market. Though the lobster fishery constitute only about $0.1 \%$ of the total marine fish landing along the Indian coast (Radhakrishnan and Manisseri 2001), more than $90 \%$ of the lobsters landed are exported. Initially, lobsters were exported as frozen tails. Since the late 80's demand for live lobsters has increased in the Southeast Asian markets and it fetches maximum unit value, compared to any other marine product. Due to increasing demand for live lobsters, many lobster holding centers have been established in the landing centres including Chennai, a major centre for export of live lobsters.

Live transport of spiny lobsters has improved from merely keeping them alive for a few hours in moist intertidal beach sand to the most sophisticated packing in thermocool insulated boxes. The lobsters are given a cold shock prior to live packing by dipping them in sea water at $13-16^{\circ} \mathrm{C}$ temperature which is the temperature maintained in live packing too. This sudden shock gives an anesthetic effect to lobsters and reduces its metabolic rate during transport. Initially, ice blocks kept in aluminum containers were placed inside the tanks to reduce the sea water temperature to give cold shock to lobsters. Few lobster exporters later installed chilling plants to reduce the sea water temperature. Heavy mortality occurred when lobsters were kept in water, which was passed through the chiller coils. Leaching of copper from the cupro-nickel coil used for cooling of water was found to be responsible for the mortality of lobsters (Vijayakumaran, Pers. Comm.).

The estimation of biochemical constituents helps to assess the nutritive value of an organism. It has become imperative to study how the nutritive value varies with the changes in biochemical constituents of the crustaceans, which are exposed to increased environmental pollution. Proteins are highly sensitive to heavy metal and one of the earliest indicators of heavy metal poisoning (Jacobs et al. 1977). In the tissue protein, carbohydrate and lipids play a major role as energy precursors for aquatic organisms exposed to stress conditions (Ramalingam 1980). An alteration in biochemical and physiological changes in the crab Portunus pelagicus due to copper and zinc have been reported by Hilmy et al. (1988). Similarly, Katticaran et al. (1995) reported the variations of carbohydrate and protein contents in the clam, Sunetta scripta during its exposure to copper. Villalan et al. (1988) observed that heavy metals altered protein, lipid and carbohydrate levels in the crab, Thalamita crenata. Baden et al. (1994) also reported similar changes in the distribution of glycogen in the tissues of Norway lobster, Nephrops norvegicus exposed to copper. Maharajan et al. (2010a, 2010b, 2011, 2012) observed copper accumulation, electrical conductivity, chromosome aberration and histopathological changes in various tissues of spiny lobster, P.hoamrus homarus when exposed to sub-lethal doses of copper.

Lack of information on the effects of sub-lethal doses of copper on the proximate composition of metabolically active tissues of coastal marine and estuarine shrimp species prompted us to undertake this study. The present communication describes changes in the concentrations of major biochemical components in the tissues of metabolically active organs (muscle, hepatopancreas 
and the gills) of spiny lobster, P. homarus homarus on exposure to two sub-lethal doses of copper over 28 days. (DoE).

\section{Materials and Methods}

Experimental animals and acclimation

Actively moving juveniles lobster, P. homarus homarus (Average weight $180 \pm 20 \mathrm{~g}$ ) were collected from Kovalam landing centre, Chennai in Tamil Nadu. Immediately after the collection, juvenile lobsters were transferred to the Madras Research Centre of Central Marine Fisheries Research Institute field laboratory, Kovalam and acclimatized them in rectangular FRP tanks (cap. 200 L) for 2 weeks before the initiation of experiments. The seawater used in acclimation tanks was treated by rapid sand filtration, bio-filtration and ultraviolet radiation. Adequate aeration was provided using air blowers, and optimum water quality parameters were maintained during the acclimation period, i.e. temperature, $\left(29 \pm 1^{\circ} \mathrm{C}\right)$, salinity $(33 \pm 1 \mathrm{ppt})$, dissolved oxygen $\left(6.4 \pm 0.8 \mathrm{mg} \mathrm{l}^{-1}\right), \mathrm{pH}(7.9 \pm 0.4)$, $\mathrm{NO}_{2}-\mathrm{N}\left(<0.02 \mathrm{mg} \mathrm{l}^{-1}\right)$ and $\mathrm{NH}_{3} / \mathrm{NH}_{4}\left(0 \mathrm{mg} \mathrm{l}^{-1}\right)$. The seawater used for acclimation and exposure experiments was free from residues of copper. A photoperiod of 12 L (0700 h-1900 h):12 D (1900 h-0700 h) was maintained. Lobsters were fed $a d$ libitum twice a day (0800 h and $1600 \mathrm{~h})$ with live marine clam Donax cuneatus. Faeces and uneaten feed was siphoned out twice a day (1000 h and $1730 \mathrm{~h})$ and $50 \%$ of water exchanged daily $(07.30 \mathrm{~h})$. In order to reduce the amount of excreted products in the test tanks, feeding was stopped $48 \mathrm{~h}$ prior to the commencement of acute bioassay tests. During the period of acclimation, the juveniles did not show any symptoms of stress or unusual behaviour. Care was taken to keep the mortality rate within $5 \%$ in the last four days before experimental exposure to copper began. Dead lobsters, if any were removed immediately from the acclimation tanks.

\section{Test chemical}

Stock solution of copper were prepared by dissolving $3.9063 \mathrm{~g}$ copper sulphate pentahydrate $\left(\mathrm{CuSO}_{4} 5 \mathrm{H}_{2} \mathrm{O}\right.$, Merck, Germany) in $100 \mathrm{ml}$ of $2 \%$ sulphuric acid solution and making upto $1000 \mathrm{ml}$ with double deionised water. It was stored in a clean standard flask at room temperature in the laboratory.

\section{Acute bioassay tests}

Acute toxicity experiments were performed in triplicate and the average mortality values were calculated using formula as described by Abbot (1925). The median lethal concentration (96-h $\mathrm{LC}_{50}$ ) and $95 \%$ confidence intervals were determined with a computer-based program described by Finney (1971). The acute 96-h LC of $P$. homarus homarus juveniles to copper was found to be $95.5 \mu \mathrm{g} \mathrm{l}^{-1}$ (95\% CL,

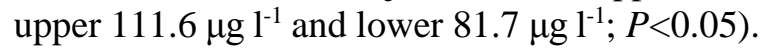

Test solutions and sub-acute tests

It has been hypothesised that sub-lethal concentrations of copper offers an excellent scope for observing the behavioural and physiological changes in 
animals (Edwards 1973). Two sub-lethal doses corresponding to $10 \%$ and $20 \%$ of 96-h LC L $_{50}$ were selected for sub-acute toxicity experiments. Concentrations of active ingredient of copper present in two sub-lethal concentrations computed from commercial-grade composition were found to be 9.55 and $19.1 \mu \mathrm{g} \mathrm{l}^{-1}$, respectively. The exact amount of active ingredient of copper present in each sublethal solution however, was not quantified. For evaluation of effects of sub-lethal concentrations, 90 randomly sampled lobsters of similar size (Average weight $180 \pm 20 \mathrm{~g} ; \mathrm{n}=10$ ) were divided into 3 groups, each group comprising of 30 intermoult juveniles (stage c) of $P$. homarus homarus. One group served as the control, while two other groups were exposed to two sub-lethal doses of copper (one group to one sub-lethal dose). A total of three replicate aquaria (50 1 capacity) were maintained for each dose and the for the control group (10 lobsters per concentration per replicate). During the exposure period, a mild aeration was provided using air pumps (BOYU, Japan) in order to maintain DO levels not less than $5 \mathrm{mg} \mathrm{l}^{-1}$. Juveniles were fed with live marine clam Donax cuneatus, ad libitum and were deprived of feed $24 \mathrm{~h}$ before exposure experiments.

In toxicological studies, chronic tests of shorter duration (21 days) have been recommended as an alternative to longer chronic tests (Maki 1979). The experiment was conducted for a period of $28 \mathrm{DoE}$ as the estimated inter-moult period of $P$. homarus homarus under the laboratory conditions was estimated to be $26 \pm 1$ days (personal observation). In order to maintain constant concentration of copper in test solutions, the entire toxic medium in each aquarium was gently siphoned out daily $(0900 \mathrm{~h})$ and renewed with freshly prepared solution of respective sub-lethal concentrations of copper. Aeration was suspended temporarily during water exchange and feeding, and care was taken that the disturbance caused to the lobsters was minimal. Neither mortality nor any visible signs of disease were observed in the lobsters exposed to sub-lethal concentrations of copper.

\section{Tissue samples and biochemical analysis}

Sampling was done on $0,7,14,21$ and 28 DoE and on each sampling occasion, 10 lobsters from each group (two experimental and one control) were sacrificed. From each lobster, sample was extracted from the tissues of muscle (MU), hepatopancreas (HP) and gills (GL). Extracted tissue samples from respective organs of 1 or 2 animals were pooled to constitute a single sample; thus three such samples (MU, HP and GL) were made for each group. Lobsters from control group were similarly sampled at the same time as treated lobsters. Concentrations of biochemical constituents (proteins, carbohydrates and lipids) in different tissues were estimated by following standard procedures. The total protein (TP) and the total carbohydrate (TC) concentrations in different tissues were determined according to the methods of Lowry et al. (1951) and Roe (1955). The total lipid (TL) content was estimated by the method of Barnes and Blackstock (1973). Accuracy of the analytical methods was tested against prepared standards and deviations from real standard values are expressed as coefficient of variation (c.v. \%). For duplicate analysis, these were $5.0-17.5 \%$ for the TP, $4.0-16.5 \%$ for the TC, and 6-17.6\% for the TL. For the purpose of comparison, concentrations 
of biochemical constituents are expressed in terms of $\mathrm{mg}^{-1}$ of wet tissue. Variation in concentrations of biochemical constituents in test lobsters are expressed as the percent change from control (100\%) and concentrations $>100 \%$ and $<100 \%$ indicate increase and decrease over control, respectively.

\section{Statistical analysis}

Fluctuations in concentrations of biochemical components in different treatment groups and organs were assessed by analysis of variance (ANOVA) (Underwood 1997) with DoE and concentration as sources of variation. Because the variances were not homogenous and/or the residual departed from normality as indicated by Cochran's test (Winer et al. 1991), all the data were subjected to transformations used in the statistical analysis. If ANOVA results were found significant, multiple comparisons between different means of biochemical components of control and test shrimps were made by Tukey-Kramer test for high significant differences (HSD) (Zar 1996). Significance in all statistical tests was judged at a $P<0.05$ level. Unless otherwise indicated, the results are presented as mean $\pm 1 \mathrm{SE}$ of replicate tanks.

\section{Results}

Physico-chemical parameters and biochemical analyses

Neither mortality nor visible disease signals were observed in the lobsters exposed to sub-lethal concentrations of copper. Physico-chemical characteristics of seawater did not vary significantly both during the acclimatisation and exposure periods $(P>0.05)$. Measured water quality parameters fell within the levels recommended for the survival of spiny lobster (Chien 1992). The first reaction following exposure to copper appeared after 7 DoE. At that time, it was noted that test lobsters failed to consume the normal ration of food. After $14 \mathrm{DoE}$, test lobsters completely rejected food, while the control lobsters continued to feed normally throughout 28 DoE. No statistical difference in the biochemical analyses was found between the replicate tissue samples of different organs $(P>0.05)$.

\section{Copper induced changes in proximate composition}

\section{Changes in the TP Levels}

Levels of the TP in different tissues of control and exposed lobsters during the exposure period are depicted in Fig.1. The TP concentrations were significantly lower in test lobsters than those of controls on all DoE $(P<0.01)$. The rate of depletion was found to be highly time and tissue dependent. The order of percent decrease of the TP concentrations in different tissues at the end of $28 \mathrm{DoE}$ was observed to be MU>HP>GL. A progressive depletion in the TP levels of test lobsters was recorded in the tissues of GL and MU during the exposure period. Significant variation in the TP content between exposure concentrations of 9.55 and $19.1 \mu \mathrm{g}^{-1}$ was noticed $(P>0.01)$. The levels of hepatic protein of test lobsters were found to be almost similar to that of control lobsters on 0 and $7 \mathrm{DoE}$ but 
depletion was more prominent on 14, 21 and 28 DoE (Fig. 1). The magnitude of depletion in the hepatic protein was directly proportional to the concentration of copper. Higher percent depletion in the hepatic protein was observed in test lobsters exposed to $19.1 \mu \mathrm{g} \mathrm{l^{-1 }}$ compared to those exposed to $9.55 \mu \mathrm{g} \mathrm{l}^{-1}$ of copper $(P<0.05)$.
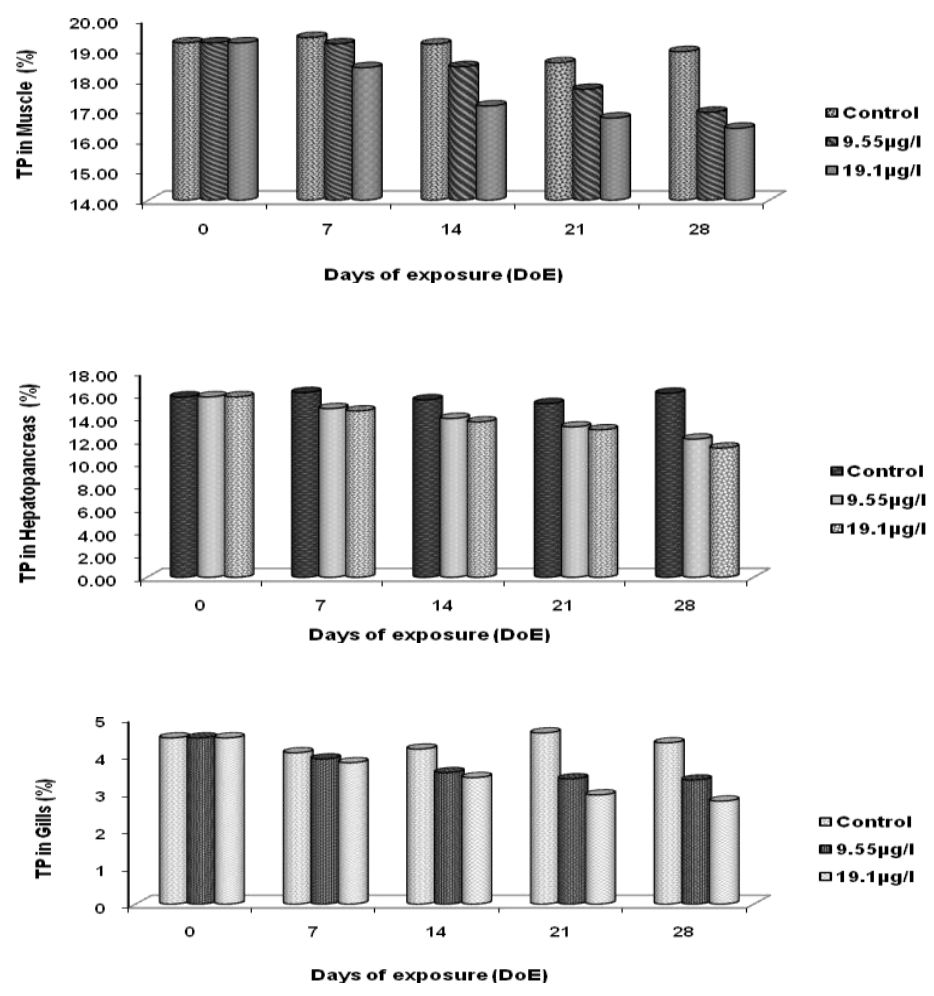

Figure 1. Changes in the total protein (TP) levels in different tissues (\% of wet tissue) of the juvenile lobster, $P$. homarus homarus on exposure to two sublethal doses (9.55 and $\left.19.1 \mu \mathrm{g} \mathrm{l}^{-1}\right)$ of copper.

Changes in the TC Levels

Levels of the TC in different tissues of test lobsters and controls during the exposure period are shown in Fig. 2 The levels of the TC in the GL tissues of test lobsters were slightly higher $(\sim 3 \%)$ than the control lobsters on 0 DoE but thereafter concentrations reduced significantly with the progress of the exposure period $(7,14,21$ and $28 \mathrm{DoE})$. No significant variation in the TC levels in the test lobsters between two exposure concentrations in the studied tissues was observed $(P>0.05)$. The depletion in the TC levels in the HP of test lobsters was significant with the progress in the period of exposure. Concentrations of hepatic carbohydrate in the test lobsters ranged from $1.32 \pm 0.03 \%(0 \mathrm{DoE})$ to $0.78 \pm 0.03 \%$ (23 DoE) over control lobsters (100\%). The levels of the TC in the MU of test lobsters exhibited a biphasic pattern: higher concentrations on $0 \mathrm{DoE}$ and $7 \mathrm{DoE}$ and lower on $14 \mathrm{DoE}$ and $21 \mathrm{DoE}$ and $28 \mathrm{DoE}$. The order of percent decrease in 
the TC levels in the studied tissues on the last day of exposure (28 DoE) was found to be $\mathrm{HP}>\mathrm{MU}>\mathrm{GL}$.
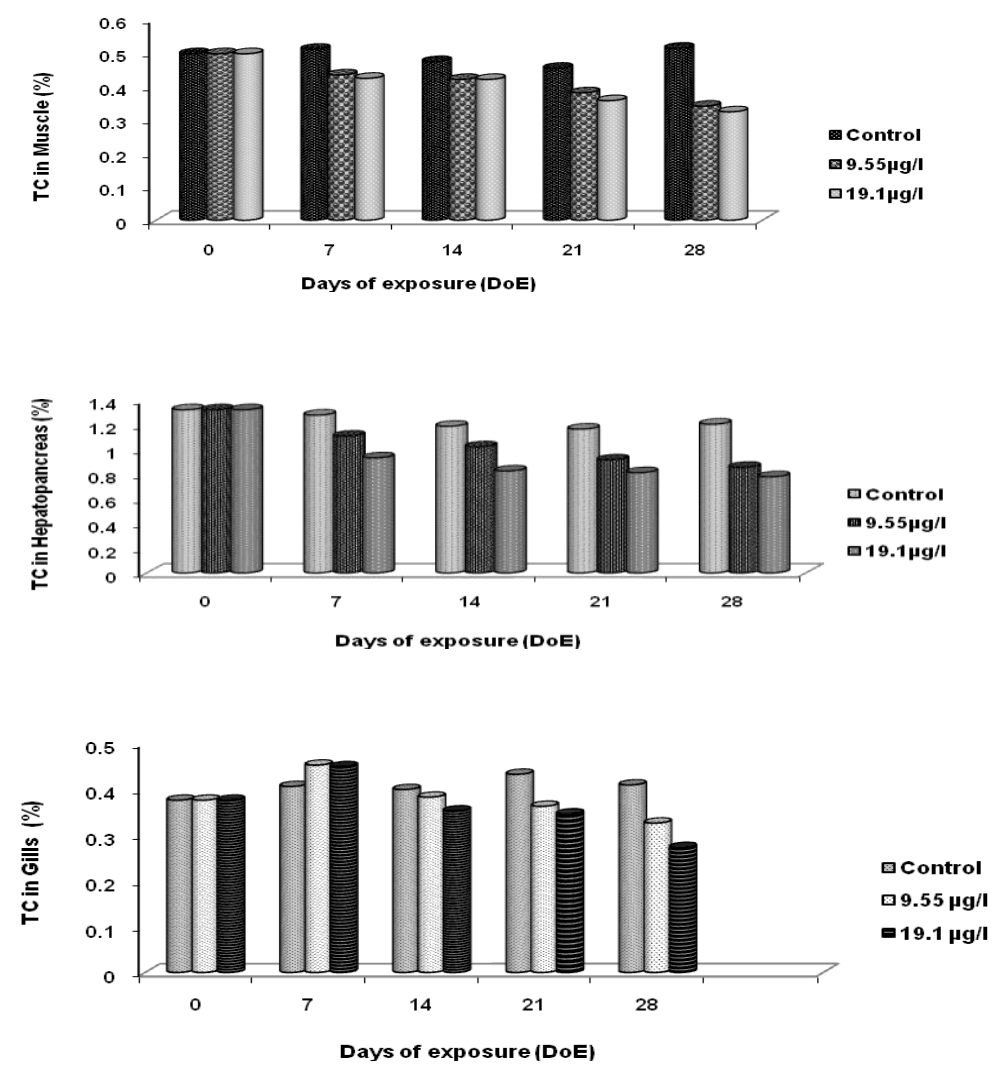

Figure 2. Changes in the total carbohydrate (TC) levels in different tissues (\% of wet tissue) of the juvenile lobster, $P$. homarus homarus on exposure to two sublethal doses $\left(9.55\right.$ and $\left.19.1 \mu \mathrm{g}^{-1}\right)$ of copper.

Changes in the TL Levels

Levels of the TL in different tissues of the test lobsters and controls during the exposure period are depicted in Fig.3. In general, the TL concentrations in all the studied tissues of lobsters exposed to sub-lethal doses of copper were significantly lower than those in controls $(P<0.05)$. The percent decrease in the hepatic lipid was higher in the HP than in the tissues of GL and MU and the order of percent decrease on $28 \mathrm{DoE}$ was found to be $\mathrm{HP}>\mathrm{MU}>\mathrm{GL}$. 

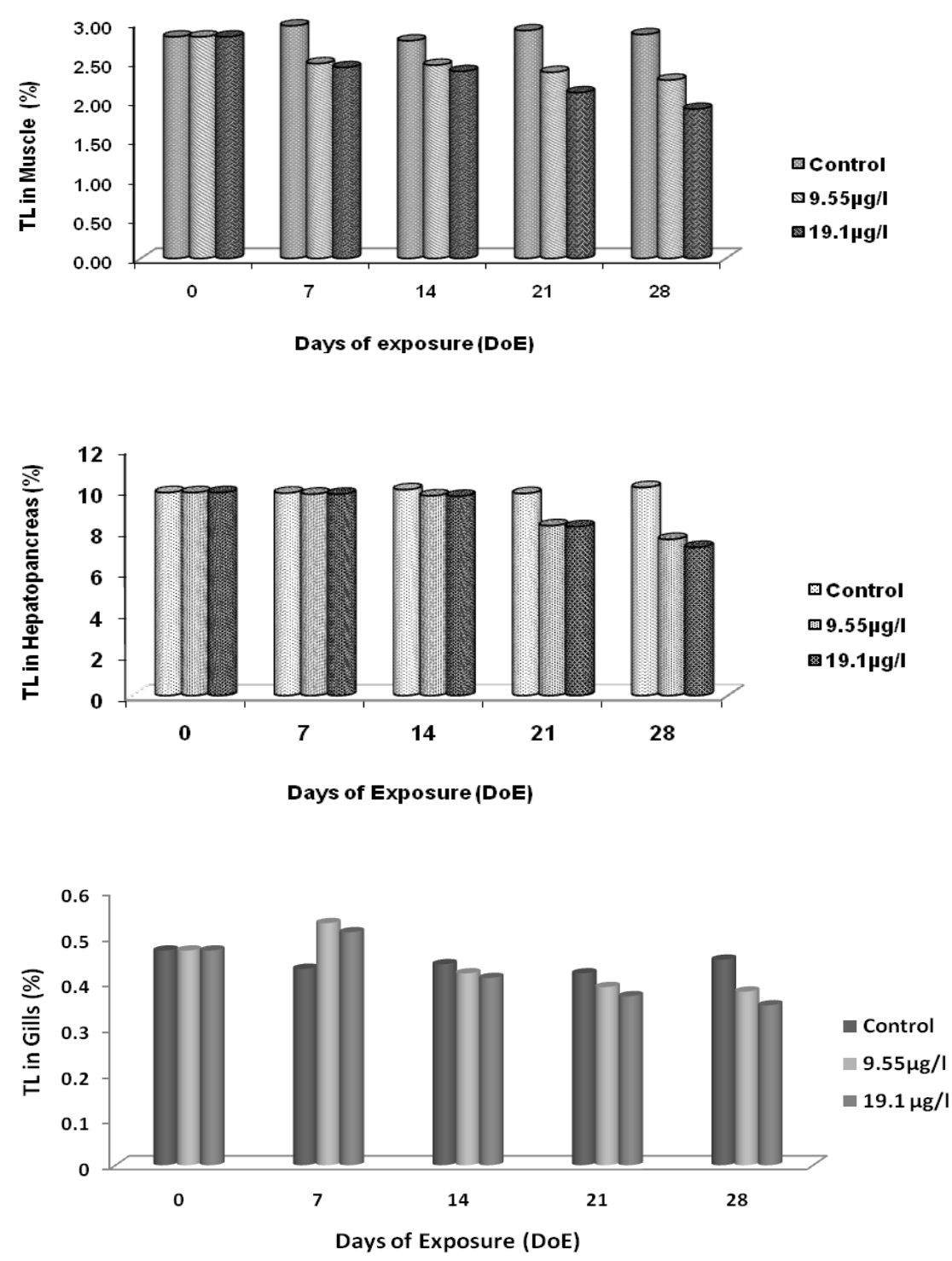

Figure 3. Changes in the total lipid (TL) levels in different tissues (\% of wet tissue) of the juvenile lobster, $P$. homarus homarus on exposure to two sublethal doses $\left(9.55\right.$ and $\left.19.1 \mu \mathrm{g}^{-1}\right)$ of copper.

\section{Discussion}

Biochemical changes induced by copper stress are due to disturbed metabolism manifested by inhibition of enzymes, retardation of growth and reduction in the fecundity and longevity of the organism. Most of the heavy metals act as metabolic depressors and generally affect the activity of biologically active molecules such as proteins, carbohydrates and lipids. The response of an 
organism to deficient as well as excess biologically available copper involves metabolic processes. These processes are biochemically driven and physiologically expressed on the health and well-being of the organism; "Copper is a key element in the biologic processes of life and an essential constituent of a great number of enzymatic systems". Since these enzymes are organometallic compounds, the relationship between organic and metal is important. Deviations from these relationships can exist as a result of excess or deficient levels of copper or the genetic makeup of the organism. Besides enzymes, other organics are involved in the transport, storage, and metabolism of copper. Like enzymes, maintenance of the proper metal-organic relationship is critical to physiology of the organism. The present study indicates, After $28 \mathrm{DoE}$, the tissues of MU, HP and GL exhibited significant depletion in the concentrations of major biochemical constituents perhaps due to stress induced by copper.

\section{Effect of copper on the TP levels}

Protein is one of the important biochemical components and plays an important role in metabolic pathways and biochemical reactions. Under extreme stress conditions, protein supply energy in metabolic pathways and biochemical reactions. Therefore, an assessment of the TP content in different tissues could be used as a diagnostic tool for determining the physiological status of an organism (Prasath and Arivoli 2008). Proteins are the major energy reserves in crustaceans. The sequence of utilization of these reserves and the relative importance of the muscle tissue as storage organs during adverse conditions however vary among species (Armitage et al. 1972; Barclay et al. 1983; White and Rainbow 1986). Contrastingly, in the spiny lobster $P$. ornatus, the hepatopancreas is reported to be a more sensitive indicator of physiological stress than the muscle tissue (Trendal and Prescott 1989). In the present study, the total protein in the muscle, hepatopancreas and gills of $P$. homarus homarus showed decreasing trend as the duration of exposure to copper increased (MU: $19.39 \%$ to $16.38 \%$, HP: $16.19 \%$ to $11.33 \%$ and GL: $4.60 \%$ to $2.77 \%$ ). It is likely that the observed reduction in total protein of $P$. homarus homarus is due to a direct consequence of the stress imposed by copper. The depletion of total protein suggests an increased proteolysis and possible utilization of the products of their degradation for metabolic purpose. The decreased protein level during exposure to pollutants may be due to increased catabolism and decreased anabolism of proteins as reported in freshwater bivalve Parrysia corrugata (Deshmukh and Lomte 1998). A decrease in protein content in shrimps in mangrove crab Sesarma brockii increases the amino acid pool which may contribute towards its conversion to detoxification mechanism of the heavy metal, cadmium (Kannupandi et al. 2001). A plausible explanation for such depletion of the TP levels in the tissues of GL and MU of test lobsters might be due to the enhanced proteolytic activity in these organs under heavy metal stress. The depletion in the TP might be due to the diversification of energy to accomplish the impending energy demands when of animals are under toxic stress. The decreased protein concentrations might also be attributed to the destruction or necrosis of cells and consequent impairment in protein synthesis machinery. Copper causes adverse effects on the lysosomal membrane as stabilizers and release nucleases and 
proteases thereby affecting the RNA and protein metabolism. Subsequently, the lower rate of protein synthesis depends on the reduced availability of ATP or an increased activity of proteolytic lysosomal enzymes (Jana and Choudhari 1984). Concentration of copper in the medium as well as the exposure duration influenced the protein profile in P.homarus homarus. Similar alterations due to copper was highlighted the crab Carcinus maenas (Wright and Brewer 1979) and the penaeid prawn Penaeus indicus (Seenivasan 1988). Copper accumulation is also a factor resulting in the decrease of protein. Similarly, Krishnamoorthy and Subramanian (1995) reported a decrease in the protein content during the process of copper accumulation in freshwater prawn Macrobrachium lamerrei lamerrei. The initial declining levels of protein may be attributed to the higher rate of energy production at the onset of various enzymatic blockages. It is known that copper blocks the mRNA synthesis and thereby the protein synthesis at the level of transcription. However, copper inhibits the action of enzyme protease reflecting a steady decline in the total percentage of protein.

\section{Effect of copper on the TC levels}

Carbohydrates form an important biochemical constituent of an animal tissue which acts as building blocks of the cells and they are the primary and immediate source of energy. During the exposure period, the TC levels decreased in all the studied tissues, the depletion was more significant in the HP followed by GL and MU tissues of test lobsters. In the present study the total carbohydrate in the MS, HP and GL of $P$. homarus homarus showed decreasing trend with increasing concentration of copper (MS: $0.51 \%$ to $0.32 \%$, HP: $1.32 \%$ to $0.78 \%$ and GL: $0.43 \%$ to $0.27 \%$ ). But a narrow increase is observed during 7 days of copper exposure in gills $(0.43 \%$ to $0.45 \%)$. The depletion of the TC may be due to its rapid utilisation to meet the reduced energetic efficiency under the impact of copper. Carbohydrate metabolism is broadly divided into the anaerobic segment or glycolysis in which the breakdown of glucose or glycogen through EmbdenMeyerhaf pathway occurs and the aerobic segment that consists of oxidation of pyruvate to acetyl co-A to be utilized through citric acid cycle (Nelson and Cox 2005). As a consequence of hypoxia, the metabolic pathway is shifted from aerobiosis to anaerobiosis and a strong suppression of the specific activities of enzymes involved in glycolysis and glycogen metabolism. These conditions might have depleted the TC levels in the lobsters exposed to copper in order to meet the increased energy demands as carbohydrates form the major source of energy under stressful conditions (Hochachka and Somero 1984). Carbohydrate metabolism is not considered to be a major energy source in fish (Walton and Cowey 1982), but its importance increases during hypoxia because of activation of anaerobic glycolysis. This may explain the observed depletion of the TC levels in test lobsters during the later stages of exposure as a result of increased demand of these molecules to provide energy for the cellular biochemical processes under hypoxic conditions induced by copper. The crustacean hepatopancreas is the vital organ involved in such diverse metabolic activities as synthesis and secretion of enzymes and it is also the major organ of detoxification (Thaker and Hariots 1989). Changes in the percentage of carbohydrate in response to differential 
concentrations as an indirect response to internal hypoxia is well explained in cat fish Heteropneustes fossilis (Misshra and Srivastava 1983). In P.homarus homarus also, a decrease in percentage of total carbohydrate in muscle and hepatopancreas has been induced by copper. Excess in dietary copper has been shown to cause lower percentage of carbohydrate in Homarus americanus. Similar result is evidenced by Jana and Sahana (1988) in fresh water fish Clarias batrachus. The association between carbohydrate and copper metabolism is complex and reduces its bioavailability in Amphora coffeaeformis (Brown et al. 1988). However, on exposure to heavy metal, glycogen content was found to be reduced in the hepatopancreas and muscle tissues of brook trout, (Mckim and Benoit 1971). Glycogen plays an important role as a readily mobilized storage form of carbohydrate in muscle (Stryer 1988), which decreases during toxicity as evidenced also in $P$. homarus homarus. Similarly, the carbohydrates decline in the gills and they deposit as granules on the lamellae interrupting the uptake of oxygen. This is consistent with the earlier studies in Norway lobster, Nephrops norvegicus resulting in hypoxic condition (Baden et al. 1994), where the binding of oxygen with haemoglobin decreases with the increase in concentration of copper, thereby resulting in hypoxia (Depledge and Bjerregaard 1989). The carbohydrate, may have been used to fuel detoxification mechanism operating within the animal as reported in P. longipes and Jasus lalandii (Cockcroft 1997). In the bivalve Sunetta scripta, the percentage of total carbohydrate significantly declined on exposure to copper, which may be attributed to the effect of copper on phosphofructokinase which is one of the limiting enzymes in the glycolytic pathway and causes depression in the activity of the enzyme that contributes to the reduction of carbohydrate content (Katticaran et al. 1995).

\section{Effect of copper on the TL levels}

The TL concentrations in different tissues in copper treated lobsters in the present study were found to be significantly lower than the concentrations in the same organs of controls $(P<0.05)$. The decrement in the TL levels may be due to the increased activity of lipase, the enzyme responsible for the breakdown of lipids into free fatty acids and glycerol. Lipids constitute the rich alternate energy reserves whose calorific value is twice as that of an equivalent weight of carbohydrates and proteins and the mobilisation of lipid reserves may be due to the imposition of high energy demands to counter the toxic stress (Reddy and Rao 1989). The concentrations of the TL decreased in all the tissues significantly with the progress of exposure period irrespective of exposure concentrations. The order of percent decrease within the tissues was: $\mathrm{HP}>\mathrm{MU}>\mathrm{GL}$. The considerable decrease in the TL in the HP and MU $(\sim 50 \%)$ on 0 DoE might be due to the drastic decrease in the TC levels $(\sim 45 \%)$ in the same tissues. The HP of crustaceans is analogous to that in the liver of vertebrates and is the centre of lipid metabolism (Chang and O'Connor 1983); higher levels of the TL could be expected in the HP compared to other tissues. The evidence of relatively higher lipid deposition in the hepatic tissues has been reported in the sequence of utilization of these reserves and the relative importance of the HP and MU tissue as storage organ during adverse conditions, such as stress and detoxification that are 
well documented (Armitige et al. 1972; Vijayakumaran 1990). In P. homarus homarus the effect of copper toxicity results in the reduction of total lipids as reported in crab Thalamita crenata (Villalan et al. 1988). The total lipids in the MU, $\mathrm{HP}$ and GL of $P$. homarus homarus showed decreasing trend as the duration of exposure in each concentration of copper increased (MS: $2.96 \%$ to $1.90 \%$, HP: $10.15 \%$ to $7.23 \%$ and GL: $0.47 \%$ to $0.35 \%$ ).A significant decreases in muscle and hepatopancreas weight may be due to its utilization for energy during detoxification mechanism. In the spiny lobster P. ornatus, the hepatopancreas is the most sensitive indicator of physiological stress than the muscle tissue (Trendal and Prescott 1989). The finding is in accord with the results obtained in $P$. homarus homarus, although muscle and hepatopancreas are the major energy stores. Copper has been associated with lipid peroxidation. Beckman and Zaugg (1988) reports that cuprus ions may initiate lipid peroxidation by a metal- metal reaction reducing the ferric ions rather than by promoting propagation reaction in the fish Chinook salmon Oncorhynchus tshawytscha. As the lipid reserves are ultimately transferred to the detoxification process in $P$. homarus homarus, the total percentage of lipids decline in hepatopancreas followed by muscle and gills.

\section{References}

Abbott, W.S. 1925.

A method of computing the effectiveness of an insecticide. Journal of Economic Entomology 18: 265-267.

Armitage, K.B., A.L. Buikema \& N.J. Willems Jr. 1972.

Organic constitutents in the annual cycle of the crayfish, Orconectes nais

(Faxon). Comparative Biochemistry and Physiology 41: 825-892.

Baden, S.P., M.H. Depledge \& L. Hagerman 1994.

Glycogen depletion and altered copper and manganese handling in

Nephrops norvegicus following starvation and exposure to hypoxia. Marine Research 103: 65-72.

Barclay, C.J., W. Dall \& D.M. Smith 1983.

Changes in lipid and protein during starvation and the moulting cycle in the tiger prawn. Journal of Experimental Marine Biology and Ecology 68: 229249.

Barnes, H. \& J.Blackstock 1973.

Estimation of lipids in marine animals and tissues. Detailed investigation of the sulphophosphovanillin method for total lipids. Journal of Experimental Marine Biology and Ecology 12: 103-118.

Beckman, B.R. \& W.S. Zaugg 1988.

Copper intoxication in chinook salmon (Oncorhynchus tshawytscha) induced by natural spring water: Effects on gill $\mathrm{Na}^{+}, \mathrm{K}^{+}$- Atpase, hematocrit and plasma glucose. Canadian Journal of Fisheries and Aquatic Sciences 45: 1430-1435.

Brown, L.N., M.G. Robinson \& B.D. Hall 1988.

Mechanisms for copper tolerance in Amphora coffeaeformis internal and external binding. Marine Biology (Berlin) 97: 581-586. 
Chang, E.S. \& J.D. O’Connor 1983.

Metabolism and transport of carbohydrates and lipids. In: The Biology of Crustacea, Vol. 5. Internal Anatomy and Physiological Regulation (Mantel, L.H. ed.) pp. 263-287. Academic Press, London.

Chien, Y.H. 1992.

Water quality requirements and management for marine shrimp culture.

In: Proceedings of the Special Session on Shrimp Farming (Wyban J. ed.)

pp. 30-42. World Aquaculture Society, Baton Rouge, LA, USA.

Cockcroft, A.C. 1997.

Biochemical composition as a growth predictor in male west-coast rock lobster (Jasus lalandii). Marine and Fresh Water Research 48: 845 - 856.

Depledge, M.H. 1987.

Enhanced copper toxicity resulting from environmental stress factor synergies. Comparative Biochemistry and Physiology 87: 15-19.

Deshmukh, R. \& A. Lomte 1998.

Effect of heavy metal $\left(\mathrm{CuSO}_{4}\right)$ on protein activity of fresh water bivalve, Parrysia corrugata. Journal of Ecotoxicology Monitoring 16(3): 704-708.

Edwards, C.A. 1973.

Environmental Pollution by Pesticides, Plenum Press, New York.

Finney, D.J. 1971.

Probit Analysis, (3rd edn). Cambridge University Press, Cambridge.

Hilmy, A.M., N.F.A. El-Hamid \& K.S. Ghazaly 1988.

Biochemical and physiological changes in the tissues and serum of both sexes in Portunus pelagicus (L) following acute exposures to zinc and copper. Folia Morphologica (Prague) 36: 79-94.

Hochachka, P.W. \& G. Somero 1984.

Biochemical Adaptation. Princeton University Press, Princeton, New Jersey.

Jacobs, J.M., N. Cormicheal \& J.B. Cavanagh 1977.

Ultra structural changes in the nervous system of rabbits poisoned with methyl mercury. Toxicology and Applied Pharmacology 39: 249-261.

Jana, S.S. \& M.A. Choudhari 1984.

Synergistic effect of heavy metal pollutants on senescence in submerged aquatic plants. Water Air Soil Pollution 21: 351-357.

Jana, S. \& S.S. Sahana 1988.

Effects of copper, cadmium and chromium cations on the freshwater fish

Clarias batrachus L. Physiological Bohomoslove 37: 79-82.

Kannupandi, T., G. Vijayakumar \& P. Soundarapandian 2001.

Impact of cadmium on the total protein, carbohydrate and lipid contents of the mangrove crab, Sesarma brockii, De Man. Journal of Marine Biological Association of India 48 (1 \& 2): 193-196.

Katticaran, C.M., K.Y. Mohammed Salib \& P.S. Joseph 1995.

Copper induced alterations in total carbohydrate and protein levels in bivalve, Sunetta scripta (Bivalvia). Indian Journal of Marine Science 24: 171-174. 
Krishnamoorthy, P. \& P. Subramanian 1995.

Biochemical variation during accumulation and depuration of copper in Macrobractium lamerrei lamerrei (H.M. Edwards). Bulletin of Pure and Applied Science 19A(1): 27-33.

Lowry, D.H., N.J. Rosebrough, A.L. Far \& R.J. Randal 1951.

Protein measurement with folin phenol reagent. Journal of Biological Chemistry 193: 265-275.

Maki, A.W. 1979.

Correlation between Daphnia magna and fathead minnow (Pimephales promelas) chronic toxicity values for several classes of test substances. Journal of Fisheries Research Board of Canada 36: 411-421.

Maharajan, A., S. Rajalakshmi, M. Vijayakumaran \& P. Kumarasamy 2010. Sublethal effect of copper on bioaccumulation in the spiny lobster, Panulirus homarus homarus (Linnaeus, 1758). Biological Segment 1(2) BS/1528 P: 1-8.

Maharajan, A., S. Rajalakshmi, S. Halder \& M. Vijayakumaran 2010.

Sublethal effect of copper on the frequency of electrical conductivity in the muscle tissue of spiny lobster, Panulirus homarus homarus (Linnaeus, 1758). Journal of Aquatic Biology 25(2):1-4.

Maharajan, A., B. Vaseeharan, S. Rajalakshmi, M. Vijayakumaran, P. Kumarasamy \& J.C. Chen 2011.

Effect of copper on morphology, weight and chromosomal aberrations in the spiny lobster, Panulirus homarus (Linnaeus, 1758). Biological Trace Element Research 144: 769-780.

Maharajan, A., S. Rajalakshmi, M. Vijayakumaran \& P. Kumarasamy 2012.

Sublethal effect of copper toxicity against histopathological changes in the spiny lobster, Panulirus homarus (Linnaeus, 1758). Biological Trace Element Research 145: 201-210.

Mckim.J.M. \& D.A. Benott 1971.

Effects of long term exposures to copper on survival, growth and reproduction of brook trout, Salvelinus jontinalis. Journal of Fisheries Research Board of Canada 28: 655-662.

Misshra, J. \& A.K. Srivastava 1983.

Malathion induced hematological biochemical changes in the Indian catfish, Heteropneustes fossilis. Environmental Research 30: 393.

Nelson, D.L. \& M.M. Cox 2005.

Lehninger Principles of Biochemistry. 4th edn. W.H. Freeman and Company, New York.

Prasath, P.M.D. \& S. Arivoli 2008.

Biochemical study of freshwater fish Catla catla with reference to mercury chloride. Iranian Journal of Environmental Health Science and Engineering 3: 109-116.

Ramalingam, K. 1980.

Studies on the effects of sublethal concentration of a few toxicants on biochemistry, physiology and histology of Tilapia mossambica (Peters) Ph.D. Thesis, University of Madras, Chennai. 
Radhakrishnan, E.V. and M.K. Manisseri 2001.

Status and management of lobster fishery resources in India. Marine

Fisheries Information Service 169: 1-3.

Reddy, M.S. \& K.V.R. Rao 1989.

In vivo modification of lipid metabolism in response to phosphamidon, methylparathion and lindane exposure in the penaeid prawn, Metapenaeus mononceros. Bulletin of Environmental Contamination Toxicology 43: 603-610.

Roe, J.H. 1955.

The determination of sugar in blood and spinal fluid with anthrone reagent. Journal of Biological Chemistry 153: 335-343.

Seenivasan, R. 1988.

Individual and combined effect of heavy metals $(\mathrm{Ca}, \mathrm{Zn}$, and $\mathrm{Cd})$ on prawn, Penaeus indicus. M.Phil. Dissertation, Annamalai University, Tamil Nadu $42 \mathrm{pp}$.

Stryer, L. 1988.

Biochemistry, $3^{\text {rd }}$ Edn. Freeman and Co. New York.

Thaker, A.A. \& A.A. Haritos 1989.

Mercury bioaccumulation and effects on soluble peptides proteins and enzymes in the hepatopancreas of the shrimp, Callianassa tyrrhena. Comparative Biochemistry and Physiology 94: 199-205.

Trendall, J.T. \& J. Prescott 1989.

Severe physiological stress associated with the annual breeding emigration of Panulirus ornatus in the Torres Strait. Marine Ecology Progressive Series 58: 29-39.

Underwood, A.J. 1997.

Experiments in Ecology: their Logical and Interpretation using Analysis of Variance. Cambridge University Press. Cambridge, UK.

Vijayakumaran, M. 1990.

Energetics of a few marine crustaceans. Ph.D. Thesis, Cochin University of Science and Technology, Cochin.

Villalan, P., K.R. Narayanan, S. Ajmal Khan \& R. Natarajan 1988.

Proximate composition of muscle, hepatopancreas and gill in the copper exposed estuarine crab Thalamita crenata (Latreille). Proceeding II National Symposium of Ecotoxicology 55-59 pp.

Walton, M.J. and C.B. Cowey 1982.

Aspects of intermediary metabolism in salmonid fish. Comparative Biochemistry and Physiology 738: 59-79.

White, S.L. \& P.S. Rainbow 1986.

Accumulation of Cadmium by Palaemon elegans (Crustacea: Decapeda). Marine Ecology Progressive Series 32: 17-25.

Winer, B.J., D.R. Brown \& K.M. Michels 1991.

Statistical principles in experimental design. 3rd edn. McGraw-Hill, New York. 
Wright, D.A. \& C.C. Brewer 1979.

Cadmium Mar. turnover in the shore crab Carcinus maenas. Marine Biology 50: 151-156.

Zar, J.H. 1996.

Biostatistical Analysis. Prentice Hall, Upper Saddle River, New Jersey, USA. 